\title{
Chronic obstructive pulmonary disease and risk of lung cancer: a meta-analysis of prospective cohort studies
}

\author{
Xinyue Zhang ${ }^{1}$, Ning Jiang ${ }^{2}$, Lijuan Wang ${ }^{3}$, Huaman Liu ${ }^{4}$ and Rong $\mathrm{He}^{3}$ \\ ${ }^{1}$ Department of Lung Disease, The First Clinic Medical College, Shandong Traditional Chinese Medicine University, Jinan, \\ Shandong Province, China \\ ${ }^{2}$ Department of Traditional Chinese Medicine, Maternal and Child Health Care of Shandong Province, Key Laboratory of Birth \\ Regulation and Control Technology of National Health Family Planning Commission of China, Jinan, Shandong Province, \\ China \\ ${ }^{3}$ Department of Lung Disease, The Affiliated Hospital of Shandong Traditional Chinese Medicine University, Jinan, Shandong \\ Province, China \\ ${ }^{4}$ Department of Internal Medicine, The Affiliated Hospital of Shandong Traditional Chinese Medicine University, Jinan, \\ Shandong Province, China \\ Correspondence to: Ning Jiang, email: jiangn5678@126.com \\ Keywords: chronic obstructive pulmonary disease, lung cancer, meta-analysis, relative risk \\ Received: April 19, $2017 \quad$ Accepted: July 25, $2017 \quad$ Published: August 18, 2017 \\ Copyright: Zhang et al. This is an open-access article distributed under the terms of the Creative Commons Attribution License 3.0 \\ (CC BY 3.0), which permits unrestricted use, distribution, and reproduction in any medium, provided the original author and source \\ are credited.
}

\section{ABSTRACT}

Background: Studies exploring the association between chronic obstructive pulmonary disease (COPD) and lung cancer have yielded mixed results. We conducted a meta-analysis of the published prospective cohort studies to have a clear understanding about this association.

Methods: We searched the MEDLINE and EMBASE databases from inception to December 31, 2016. Bibliographies were also reviewed for additional information. Random-effects model was used to calculate summary relative risk (SRR) and corresponding $95 \%$ confidence interval (CI).

Results: Eighteen prospective cohort studies were part of this meta-analysis, involving 12,442 lung cancer cases with a median duration of follow- up of 5 years (range: 1.5-20 years). A history of COPD, emphysema or chronic bronchitis conferred SRRs of 2.06 (95\% CIs: 1.50-2.85; $n=14$ studies), 2.33 (95\% CIs: 1.56-3.49; $n=4$ studies) and 1.17 (95\%CIs: $0.79-1.73 ; n=3$ studies), respectively. Stratification by COPD severity yielded SRR of 1.46 (95\% CIs: 1.20-1.76) for mild, 2.05 (95\% CIs: 1.67-2.52) for moderate and $2.44(95 \%$ CIs: $1.73-3.45$ ) for severe COPD, respectively. There were similar risk estimations for never and ever smokers. The SRR was statistically higher for squamous cell cancer than that for adenocarcinoma and for small cell cancer of the lung $(P<0.05)$.

Conclusion: This meta-analysis indicated a significantly increased risk of lung cancer for COPD, emphysema, but not for chronic bronchitis. For the prevention of lung cancer, it is of importance for early detection of COPD in lung cancer surveillance.

\section{INTRODUCTION}

Lung cancer and chronic obstructive pulmonary disease (COPD) are two major public health problems. According to the Global Burden of Disease (GBD) 2013, these two diseases are among the six non-communicable leading causes of years of life lost globally [1]. World Health Organization estimated that COPD affects about 65 million people in the world, of which 5\% died in 2005 and $90 \%$ of those deaths occurred in low and middle income countries [2]. In almost every country lung cancer is within the top leading causes of death [3]. It is 
estimated that by 2030 it will still be one of the main causes of death [4].

COPD is characterized by progressive and incompletely reversible airflow obstruction in the lungs. Epidemiological studies have observed an association between these two diseases and mechanisms are most likely related to systemic inflammation, oxidative stress, lung repair mechanisms [5]. Though the results were fairly heterogeneous, two meta-analyses till now have evaluated COPD as a risk factor for lung cancer $[6,7]$. The most recent report included literatures up to August, 2010, which included 31 case-control and 8 cohort studies [8-15], and found the overall relative risks (RR) $(95 \%$ confidence interval $[\mathrm{CI}])$ for a previous history of COPD, chronic bronchitis or emphysema of 2.22 (1.66-2.97), 1.52 (1.25-1.84) and 2.04 (1.72-2.41), respectively [6]. Since that report was published, many prospective cohort studies on this issue have emerged [15-24]. Case-control studies [25-32] reported exposure information obtained after lung cancer diagnosis; these data thus be subject to recall bias and inaccurate assessments of COPD. Moreover, selection bias is a concern in case-control studies. Therefore, to obtain a more accurate and precise estimated effect of COPD on risk of lung cancer, we conducted a comprehensive meta-analysis of prospective cohort studies using our own methods and criteria in the selection of studies, in the presentation of data, and in our conclusions and interpretation of the evidence. This meta-analysis followed the guideline on meta-analysis of observational studies in epidemiology (MOOSE) [33].

\section{RESULTS}

\section{Search results}

Based on the study selection criteria, we identified a total of 2,439 potentially relevant articles (2,318 articles from MEDLINE database and 121 articles from EMBASE database). Among these 2439 articles, 72 were considered potentially relevant and their full texts were retrieved for further evaluation. Fifty-nine were excluded for various reasons: 17 did not evaluate this association, 4 reported the same population [10, 34-36], 2 did not report RR and/or $95 \%$ CI [37, 38], 4 did not adjust for smoking [39-42], and 3 provided only estimates for percentiles of lung function scores $[8,43,44]$. In addition, 5 more articles were identified by studying the cross-reference list. Therefore, a total of 18 cohort studies were used for this meta-analysis (Figure 1).

\section{Study characteristics}

Table 1 depicted the characteristics of these studies. In a total of 931,627 of participants, 12,442 lung cancer cases were observed after a median duration of followup of 5 years (range: 1.5-20 years). The continents or countries in which the studies were conducted were as follows: China $(n=3)$, the United States $(n=9)$, and Europe $(\mathrm{n}=6)$. For the diagnosis of COPD, seven studies $[12-14,16,18,24,45]$ used forced expiratory volume (FEV) or radiographic evidence of emphysema, eight studies $[9,11,19,20,22,23,46,47]$ based on selfreported condition from questionnaire, and three studies $[15,17,21]$ used physician report, medical report or disease registry.

\section{Meta-analysis}

Fourteen studies representing the association between COPD and lung cancer risk were used for this analysis. The SRR was 2.06 (95\% CI: 1.50-2.85), and had high heterogeneity $\left(\mathrm{P}_{\text {heterogeneity }}<0.001, \mathrm{I}^{2}=96.7 \%\right.$; Figure 2A). There were three studies representing the risk associations for chronic bronchitis, with the SRR of 1.17 $\left(95 \%\right.$ CI: $0.79-1.73 ; \mathrm{P}_{\text {heterogeneity }}=0.027, \mathrm{I}^{2}=72.3 \%$; Figure 2B). Four studies represented the risk associations for emphysema, with the SRR of 2.33 (95\% CI: 1.56-3.49; $\mathrm{P}_{\text {heterogeneity }}=0.091, \mathrm{I}^{2}=53.5 \%$; Figure 2C).

\section{Subgroup analyses (shown in Table 2)}

\section{Study locations}

When stratified by study locations, the strong association was observed in China ( $\mathrm{SRR}=2.99,95 \% \mathrm{CI}$ : $\left.1.18-7.60, \mathrm{P}_{\text {heterogeneity }}<0.001\right)$, Europe ( $\mathrm{SRR}=2.40,95 \% \mathrm{CI}$ : $\left.1.81-3.18, \mathrm{P}_{\text {heterogeneity }}=0.116\right)$ and the USA (SRR $=1.65$, $95 \%$ CI: $\left.1.32-2.05, \mathrm{P}_{\text {heterogeneity }}<0.001\right)$.

\section{Gender}

Most of the studies reported risk estimations for men and women combined, and three studies [20-22] reported specifically for men and women. Another three studies $[13,15,18]$ consisted entirely or almost entirely of men $(>90 \%)$. In stratified analyses by gender, COPD was associated with an increased risk of lung cancer in both men and women (men: SRR $=2.04,95 \%$ CI: $1.11-3.74$, P heterogeneity $<0.001$; women: $\mathrm{SRR}=2.67,95 \% \mathrm{CI}$ : $1.27-5.59$, $\left.\mathrm{P}_{\text {heterogeneity }}<0.001\right)$. There was no gender difference in the risk estimation $(\mathrm{P}=0.289)$.

\section{Smoking status}

Three studies [11, 13, 20] reported risk estimations specifically for smoking status (never, ever, former and current smokers), and one study [47] involved only never smokers. The SRRs were 2.32 (95\% CIs: 1.42-3.77) for never smokers, 1.60 (95\% CIs: 1.28-2.01) for ever smokers, $1.63(95 \%$ CIs: $1.11-2.39)$ for current smokers and 1.32 (95\% CIs: 0.65-2.68) for former smokers, respectively. The difference were not statistically significant among the smoking status $(\mathrm{P}=0.289)$. 
Table 1: Characteristics of prospective cohort studies of chronic obstructive pulmonary disease and lung cancer risk

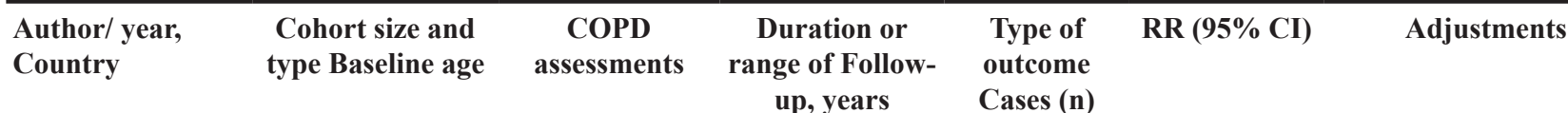

\begin{tabular}{|c|c|c|c|c|c|c|}
\hline $\begin{array}{l}\text { Oelsner et al./2016/ } \\
\text { USA [24] }\end{array}$ & $\begin{array}{l}\text { MESA, } N=6784 \\
\text { Age: } 62 \text { years; } \\
\text { M(47.1\%) }\end{array}$ & $\mathrm{CT}$ & 12 & $\begin{array}{l}\text { Death, } \\
\mathrm{N}=538\end{array}$ & $\begin{array}{c}\text { RR: } 1.84 \\
(1.09-3.12)\end{array}$ & $\begin{array}{l}\text { Age, sex, race/ethnicity, } \\
\text { BMI, site, smoking, } \\
\text { coronary artery calcium } \\
\text { score and education }\end{array}$ \\
\hline $\begin{array}{l}\text { Marcus et al./2015/ } \\
\text { England [23], }\end{array}$ & $\begin{array}{l}\text { LLPi, } \mathrm{N}=8760 \\
\text { Age: } 45-79 ; \mathrm{M} \\
\quad(47.8 \%)\end{array}$ & $\begin{array}{c}\text { Self-report HES } \\
\text { database }\end{array}$ & 8.7 & $\begin{array}{c}\text { Incidence } \\
\mathrm{N}=237\end{array}$ & $\begin{array}{l}\text { HR: } 2.43 \\
(1.79-3.30)\end{array}$ & $\begin{array}{c}\text { Age, sex, smoking } \\
\text { duration, } \\
\text { prior diagnosis of } \\
\text { pneumonia, asthma, prior } \\
\text { diagnosis of malignant } \\
\text { tumor, and family history } \\
\text { of lung cancer }\end{array}$ \\
\hline $\begin{array}{l}\text { Aldrich et al./2015/ } \\
\text { USA [22] }\end{array}$ & $\begin{array}{c}\text { SCCS, } \mathrm{N}=26,927 \\
\text { Age: } 45-79 ; \mathrm{M} \\
(33.1 \%)\end{array}$ & CMS & 2002-2009 & $\begin{array}{l}\text { Death, } \\
\mathrm{N}=318\end{array}$ & $\begin{array}{c}\text { HR: } 2.12 \\
(1.59-2.82)\end{array}$ & $\begin{array}{l}\text { coverage time, sex, race, } \\
\text { income, education, BMI, } \\
\text { smoking, CESD-10 score } \\
\text { and comorbidity count }\end{array}$ \\
\hline $\begin{array}{l}\text { Shen et al./2014/ } \\
\text { China [21] }\end{array}$ & $\begin{array}{l}\text { General population } \\
\qquad \begin{array}{c}\mathrm{N}=20730 \\
\text { Age: } 65.9 ; \\
\mathrm{M}(64.1 \%)\end{array}\end{array}$ & ICD-9 & 7.7 & $\begin{array}{c}\text { Incidence } \\
\mathrm{N}=896\end{array}$ & $\begin{array}{c}\text { HR: } 5.38 \\
(4.52-6.40) \text { no } \\
\text { DM } \\
4.05(3.26- \\
5.03) \mathrm{DM}\end{array}$ & $\begin{array}{l}\text { Age, sex, urbanization, } \\
\text { income and co- } \\
\text { morbidities of } \\
\text { pneumoconiosis, } \\
\text { interstitial lung disease, } \\
\text { and pulmonary TB }\end{array}$ \\
\hline $\begin{array}{l}\text { Leung et al./2012/ } \\
\text { China [20] }\end{array}$ & $\begin{array}{c}\quad \mathrm{N}=62529 \\
\text { Aged }>65 \text { years; } \mathrm{M} \\
(35.5 \%)\end{array}$ & $\begin{array}{l}\text { Physician } \\
\text { diagnosed }\end{array}$ & 8.3 & $\begin{array}{l}\text { Mortality } \\
N=1297\end{array}$ & $\begin{array}{l}\text { HR: } 1.86 \\
(1.58-2.19)\end{array}$ & $\begin{array}{l}\text { Age, sex, BMI, marital } \\
\text { status, education, } \\
\text { housing, alcohol, family } \\
\text { history of malignancy }\end{array}$ \\
\hline $\begin{array}{l}\text { Fan et al./2011/ } \\
\text { China [19] }\end{array}$ & $\begin{array}{l}\text { tin miners of } \mathrm{YTC} \\
\mathrm{N}=9295 \\
\text { Aged }>40 \text { years; } \mathrm{M} \\
\quad(93.6 \%)\end{array}$ & Self-report & 1992-2001 & $\begin{array}{c}\text { Incidence } \\
\mathrm{N}=502\end{array}$ & $\begin{array}{c}\text { HR: } 1.50 \\
(1.24-1.81) \\
\text { CB }\end{array}$ & $\begin{array}{c}\text { Age, sex, education, } \\
\text { smoking status, pack- } \\
\text { years, occupational radon } \\
\text { and arsenic exposure and } \\
\text { prior pulmonary disease }\end{array}$ \\
\hline $\begin{array}{l}\text { de Torres et } \\
\text { al./2011/USA [18] }\end{array}$ & $\begin{array}{c}\text { BODE, } \mathrm{N}=2507 \\
\text { Age: } 65 \\
\mathrm{M}(92 \%)\end{array}$ & $\begin{array}{c}\mathrm{DL}_{\mathrm{CO}<80 \%} \\
\mathrm{FEV} 1<70 \%\end{array}$ & 5 & $\begin{array}{c}\text { Incidence } \\
\mathrm{N}=250\end{array}$ & $\begin{array}{c}\text { HR: } 1.76 \\
(1.15-2.69)\end{array}$ & $\begin{array}{l}\text { Age, sex, BMI, pack-year } \\
\text { history, smoking status, } \\
\text { GOLD stages, DL }{ }_{\mathrm{CO}}, \mathrm{IC} / \\
\text { TLC }\end{array}$ \\
\hline $\begin{array}{l}\text { Rodriguez et } \\
\text { al./2010/UK [17] }\end{array}$ & $\begin{array}{c}\text { GPRD: } \mathrm{N}=1927 \\
\text { Control } \mathrm{N}=16546 \\
\text { Age: } 40-89, \mathrm{M} \\
(72.3 \%)\end{array}$ & Medical record & 3.2 & $\begin{array}{c}\text { Incidence } \\
\mathrm{N}=130\end{array}$ & $\begin{array}{l}\text { HR: } 3.95 \\
(2.39-6.52)\end{array}$ & $\begin{array}{l}\text { Age, sex, calendar } \\
\text { year, smoking, PCP } \\
\text { visits, referral and } \\
\text { hospitalizations, } \\
\text { ischaemic heart disease } \\
\text { and depression. }\end{array}$ \\
\hline
\end{tabular}

Mortensen/2010/

USA [15],

et al/2009/

Netherlands [16]

\footnotetext{
a previous

diagnosis of pneumonia

$\mathrm{N}=40744$

Aged $\geq 65$ years

M (98.1\%)

$\mathrm{N}=3371$ patients with peripheral arterial disease

Age: 66; M (73\%)
}

$\begin{array}{ccc} & \text { Incidence } & \text { HR: } 1.12 \\ \text { ICD-9 } & \mathrm{N}=3760 & (1.04-1.20)\end{array}$

FEV1
Age at admission, race/ ethnic group, tobacco use and marital status

Age, gender, type of surgery, diabetes, smoking, hypercholestrolaemia, corticosteroids, statins and aspirin

(Continued) 


\begin{tabular}{|c|c|c|c|c|c|c|}
\hline $\begin{array}{l}\text { Author/ year, } \\
\text { Country }\end{array}$ & $\begin{array}{l}\text { Cohort size and } \\
\text { type Baseline age }\end{array}$ & $\begin{array}{c}\text { COPD } \\
\text { assessments }\end{array}$ & $\begin{array}{l}\text { Duration or } \\
\text { range of Follow- } \\
\text { up, years }\end{array}$ & $\begin{array}{c}\text { Type of } \\
\text { outcome } \\
\text { Cases (n) }\end{array}$ & RR $(95 \% \mathrm{CI})$ & Adjustments \\
\hline $\begin{array}{l}\text { Wilson et al./2008/ } \\
\text { USA [14] }\end{array}$ & $\begin{array}{c}\mathrm{N}=3642, \text { Age } 50- \\
79 \text { years } \\
\mathrm{M}(51.4 \%)\end{array}$ & $\begin{array}{c}\text { FEV1 } \\
\text { Or on CT }\end{array}$ & 3.7 & $\begin{array}{l}\text { Incidence } \\
\mathrm{N}=99\end{array}$ & $\begin{array}{c}\text { OR: } \\
2.09(1.33- \\
3.27) \mathrm{COPD} \\
3.56(2.21- \\
5.73) \mathrm{E}\end{array}$ & $\begin{array}{l}\text { Age, sex, cigarette } \\
\text { smoking, smoking dose } \\
\text { intensity }\end{array}$ \\
\hline $\begin{array}{l}\text { Slatore et al./2008/ } \\
\text { USA [46] }\end{array}$ & $\begin{array}{c}\text { VITAL, } N=77126 \\
\text { Age } 50-76 \text { years; } \\
\text { M }(48 \%)\end{array}$ & Self-report & 4.05 & $\begin{array}{l}\text { Incidence } \\
\mathrm{N}=521\end{array}$ & $\begin{array}{c}\text { HR } 1.45 \\
(1.13-1.87)\end{array}$ & $\begin{array}{c}\text { Age, sex, years of } \\
\text { smoking, pack-years, } \\
\text { pack-years squared }\end{array}$ \\
\hline $\begin{array}{l}\text { Purdue et al./2007/ } \\
\text { Sweden [13] }\end{array}$ & $\begin{array}{c}\text { Swedish } \\
\text { construction } \\
\text { workers } \\
\mathrm{N}=176997 \\
\mathrm{M}(100 \%)\end{array}$ & $\mathrm{FEV}_{1}$ & 15 & $\begin{array}{c}\text { Incidence } \\
\mathrm{N}=834\end{array}$ & $\begin{array}{l}1.5(1.2-1.9) \\
\text { mild } \\
2.1(1.7-2.6) \\
\text { moderate } \\
2.7(1.6-4.6) \\
\quad \text { severe }\end{array}$ & Age, smoking, \\
\hline $\begin{array}{l}\text { Turner/2007/USA } \\
{[47]}\end{array}$ & $\begin{array}{c}\text { CPS-II } \\
\mathrm{N}=448,600 \\
\mathrm{M}(27.1 \%)\end{array}$ & Self-report & 20 & $\begin{array}{l}\text { Mortality } \\
\mathrm{N}=1759\end{array}$ & $\begin{array}{c}\text { HR: } \\
0.96(0.72- \\
1.28) \mathrm{CB} \\
1.66(1.06- \\
2.59) \mathrm{E} \\
2.44(1.22- \\
4.90) \mathrm{COPD}\end{array}$ & $\begin{array}{l}\text { Age, sex, race, education, } \\
\text { marital status, BMI, } \\
\text { occupational exposures, } \\
\text { alcohol consumption, } \\
\text { vegetable/fruit/fiber } \\
\text { intake, fat intake, and } \\
\text { passive smoking }\end{array}$ \\
\hline $\begin{array}{l}\text { de Torres et } \\
\text { al./2007/Spain [12] }\end{array}$ & $\begin{array}{c}\mathrm{N}=1166, \text { Age } 54 \\
\text { years } \\
\mathrm{M}(74 \%)\end{array}$ & $\begin{array}{l}\text { FEV1 } \\
\text { Or } \\
\text { on CT }\end{array}$ & $2002-2005$ & $\begin{array}{l}\text { Incidence } \\
\mathrm{N}=23\end{array}$ & $\begin{array}{l}\text { RR 2.89 } \\
1.14-7.27 \\
\text { COPD } \\
3.13(1.32- \\
7.44) \mathrm{E}\end{array}$ & $\begin{array}{l}\text { Age, sex, pack-years of } \\
\text { smoking }\end{array}$ \\
\hline $\begin{array}{l}\text { Littman et } \\
\text { al./2004/USA [11] }\end{array}$ & $\begin{array}{c}\text { CARET: } N=17698 \\
\text { Age: } 50-69 \\
M(65 \%)\end{array}$ & Self-report & 9.1 & $\begin{array}{l}\text { Incidence } \\
\mathrm{N}=1028\end{array}$ & $\begin{array}{c}\text { COPD } \\
\text { HR } 1.29 \\
(1.09-1.53)\end{array}$ & $\begin{array}{l}\text { Age, sex, study arm, } \\
\text { education, BMI, } \\
\text { cigarettes smoked }\end{array}$ \\
\hline $\begin{array}{l}\text { Mannino et } \\
\text { al./2003/USA [10] }\end{array}$ & $\begin{array}{c}\text { NHANES I } \\
\mathrm{N}=5402, \text { Age: } 24- \\
74 \\
\mathrm{M}(45.8 \%)\end{array}$ & FEV1/FEV $<70 \%$ & 9.8 & $\begin{array}{l}\text { Incidence } \\
\mathrm{N}=113\end{array}$ & $\begin{array}{l}\text { HR: } 1.4(0.8- \\
2.6) \text { mild } \\
2.8(1.8-4.4) \\
\text { moderate/ } \\
\text { severe }\end{array}$ & $\begin{array}{l}\text { Age, sex, race, smoking } \\
\text { status, pulmonary } \\
\text { function level, pack-years } \\
\text { of cigarettes, years since } \\
\text { last smoking }\end{array}$ \\
\hline $\begin{array}{l}\text { Vestbo et al./1991/ } \\
\text { Denmark [9] }\end{array}$ & $\begin{array}{c}\mathrm{N}=876, \text { Age } 45-59 \\
\mathrm{M}(82.3 \%)\end{array}$ & Self-report & 1974-1985 & $\begin{array}{l}\text { Incidence } \\
\quad \mathrm{N}=35\end{array}$ & $\begin{array}{c}0.8(0.27-2.45) \\
\mathrm{CB}\end{array}$ & $\begin{array}{l}\text { Age, tobacco } \\
\text { consumption }\end{array}$ \\
\hline
\end{tabular}

Abbreviation: COPD, chronic obstructive pulmonary disease; MESA, Multi-Ethnic Study of Atherosclerosis; SCCS, Southern Community Cohort Study; LLPi, Liverpool Lung Project; CMS, Centers for Medicare and Medicaid Services; YTC, Yunnan Tin Corporation; BODE, Body Mass Index, Airflow Obstruction, Dyspnea, Exercise Performance; GPRD, General Practice Research Database, VITAL, VITamins And Lifestyle; CPS-II, Cancer Prevention Study II; CARET, Carotene and Retinol Efficacy Trial; NHANES I, National Health and Nutrition Examination Survey; HES, Hospital Episode Statistics; ICD, International Classification of Diseases; FEV, forced expiratory volume; CB, chronic bronchitis; CESD, Center for Epidemiologic Studies Depression Scale; DLCO, diffusion capacity for carbon monoxide.

\section{Diagnostic method of COPD}

We also performed subgroup analysis based on the methods of COPD diagnosis. The SRR in spirometry and radiographic evidence subgroup $(\mathrm{SRR}=2.02,95 \% \mathrm{CI}$ : 1.69 $-2.41, \mathrm{P}_{\text {heterogeneity }}=0.931, \mathrm{I}^{2}=0$ ) were similar with those in self-report (SRR $=1.75,95 \%$ CI: $1.40-2.19, \mathrm{P}_{\text {heterogeneity }}<0.001$, $\left.\mathrm{I}^{2}=80.2 \%\right)$ or disease registry subgroups $(\mathrm{SRR}=2.75,95 \% \mathrm{CI}$ : $0.87-8.73, \mathrm{P}_{\text {heterogeneity }}<0.0071, \mathrm{I}^{2}=99.4 \%$ ).

\section{COPD severity}

Four studies [13, 14, 16, 45] presented results specifically for the severity of COPD, and the SRRs were 1.46 (95\% CIs: $1.20-1.76 ; \mathrm{P}_{\text {heterogeneity }}=0.876, \mathrm{I}^{2}=$ $0)$ for mild, $2.05\left(95 \%\right.$ CIs: $1.67-2.52, \mathrm{P}_{\text {heterogeneity }}=0.337$, $\left.\mathrm{I}^{2}=8.1 \%\right)$ for moderate and 2.44(95\% CIs: 1.73-3.45, $\mathrm{P}_{\text {heterogeneity }}=0.438, \mathrm{I}^{2}=0$ ) for severe COPD, respectively. 


\section{Duration of follow-up}

The SRRs were 1.87 (95\% CIs: 1.36-2.59; $\mathrm{P}$ $<0.001, \mathrm{I}^{2}=89.3 \%$ ) for studies with a median duration of follow-up less than 5 years, which was similar with those for studies with a median duration of follow-up large than 5 years 2.23(95\% CIs: 1.41-3.53, $\mathrm{P}_{\text {heterogeneity }}<0.001, \mathrm{I}^{2}=96.3 \%$ ).

\section{Type of outcome}

Among these 14 cohort studies, 10 used incidence rate ratios or hazard ratio as the measure of relative risk, while four used mortality rate ratios or hazard ratio [16, 20, 22, 47]. The SRR for lung cancer incidence with history of COPD was similar with that for lung cancer mortality (Incidence: SRR $=2.06,95 \%$ CI: $1.34-3.16$, $\mathrm{P}_{\text {heterogeneity }}<0.001$; mortality: $\mathrm{SRR}=1.95,95 \% \mathrm{CI}: 1.71$ $-2.23, \mathrm{P}_{\text {heterogeneity }}=0.775$ ).

\section{Histological subtype}

Two cohort studies $[11,13]$ reported results on the association between COPD and histological subtype of lung cancer. This association was significantly positive for squamous cell cancer (SRR $=1.85,95 \% \mathrm{CI}: 1.34-2.54$, $\left.\mathrm{P}_{\text {heterogeneity }}=0.147\right)$, but null for adenocarcinoma $(\mathrm{SRR}=1.25$, 95\% CI: $\left.0.93-1.68, \mathrm{P}_{\text {heterogeneity }}=0.225\right)$ and small cell cancer $\left(\mathrm{SRR}=1.39,95 \% \mathrm{CI}: 0.74-2.61, \mathrm{P}_{\text {heterogeneity }}=0.041\right)$.

\section{Sensitivity and meta-regression analysis}

Exclusion of studies in which all subjects were reported with a previous diagnosis of pneumonia [15], peripheral arterial disease [16], or from specific occupation $[11,13]$ did not change the overall risk estimate for lung cancer $(\mathrm{SRR}=2.35,95 \% \mathrm{CI}$ : $1.69-3.26)$. We also conducted a sensitivity analysis by omitting one study at a time and calculating the SRRs for the remainder of studies, and found that there were no changes in the direction of effect when any one study was excluded (Supplementary Figure 1).

We conducted meta-regression analyses to investigate the impact of above study characteristics on the risk estimates of lung cancer. Only study locations $(\mathrm{P}=0.029)$ was found to be the significant factor, and the heterogeneity explained by the population source was $36.3 \%$.

\section{Publication bias}

Begg's $(P=0.511)$ and Egger's $(P=0.356)$ tests did not reveal evidence of publication bias, but visual inspection of the funnel plots revealed significant asymmetry. The trim-and-fill method suggested that 7 additional risk estimates were needed to balance the funnel

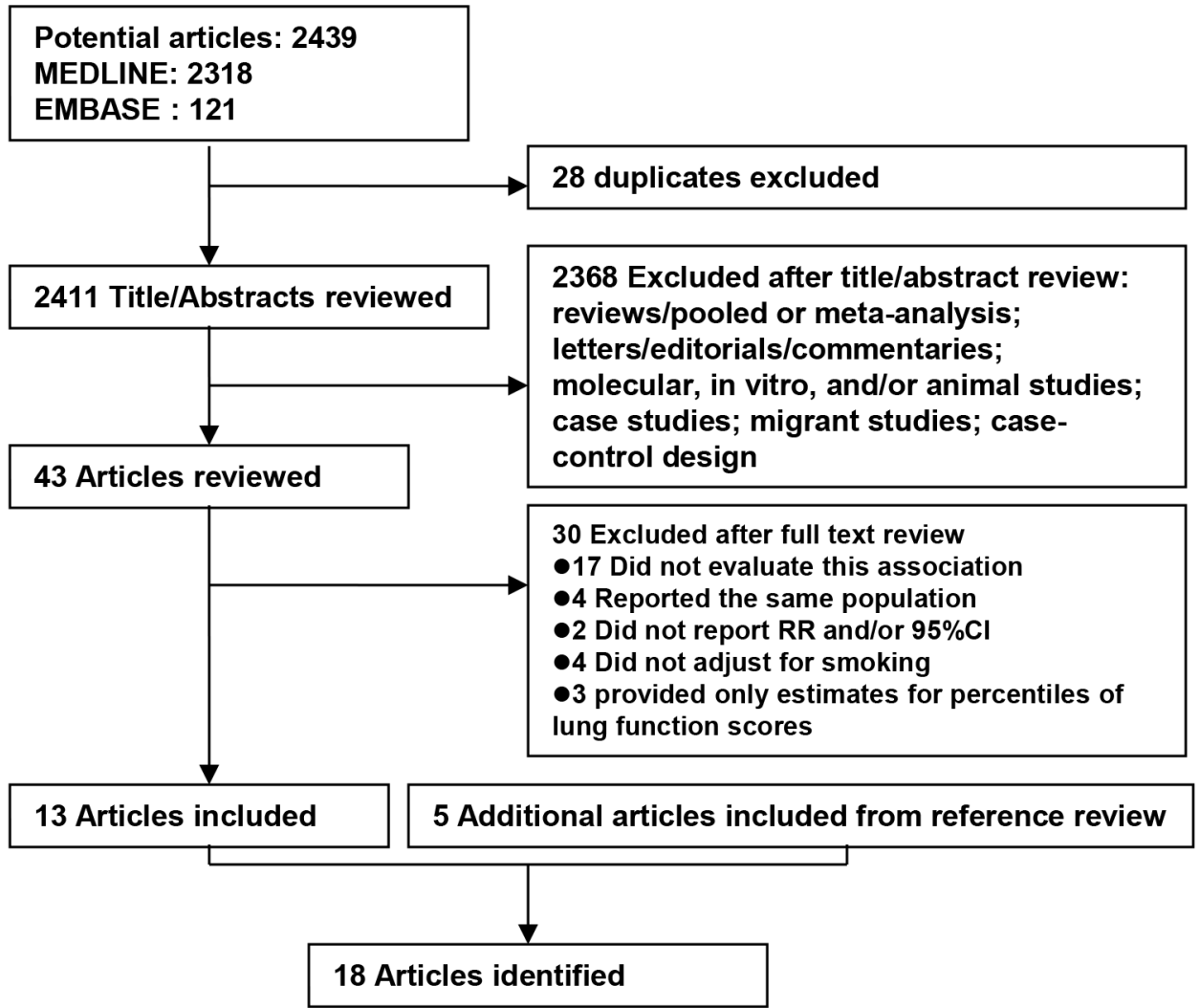

Figure 1: Flow diagram of systematic literature search on the association between chronic obstructive pulmonary disease and risk of lung cancer. 
A

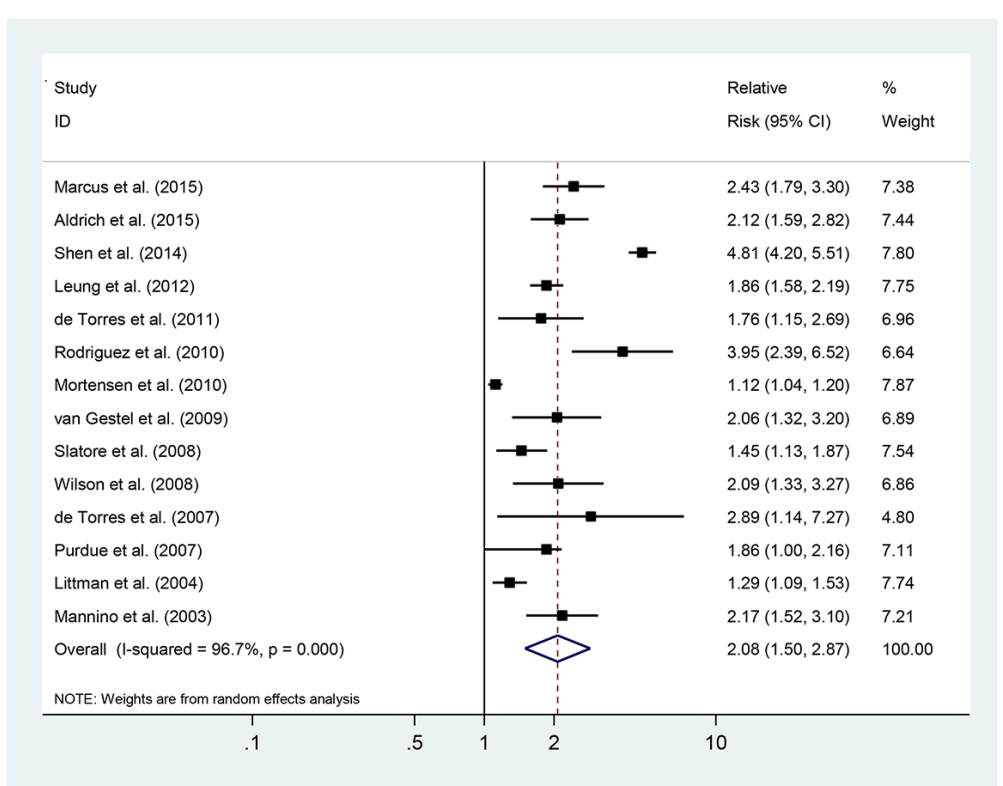

B

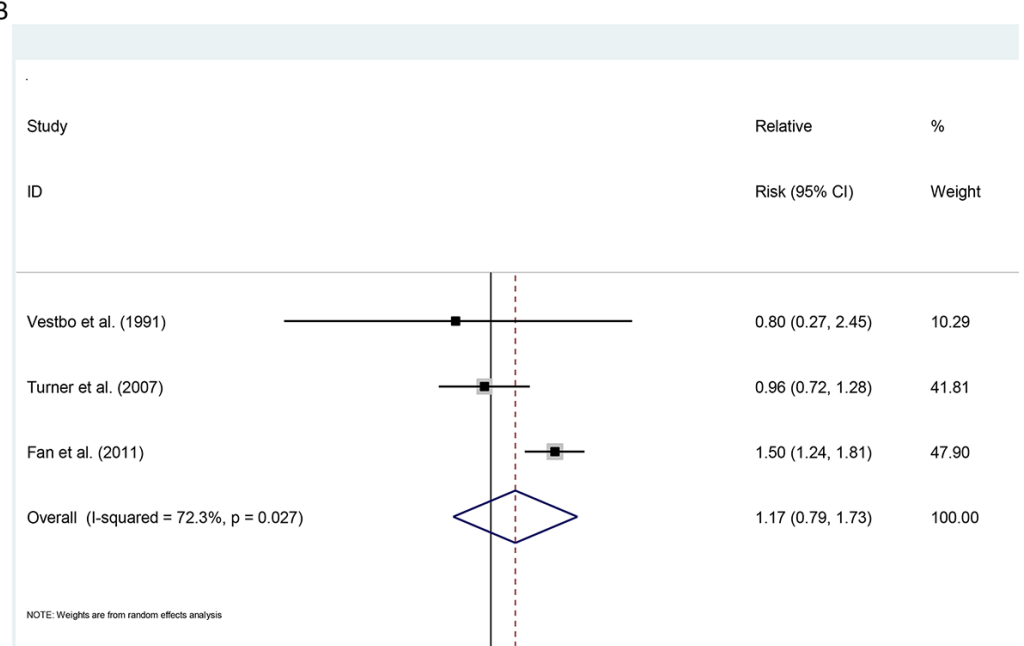

C

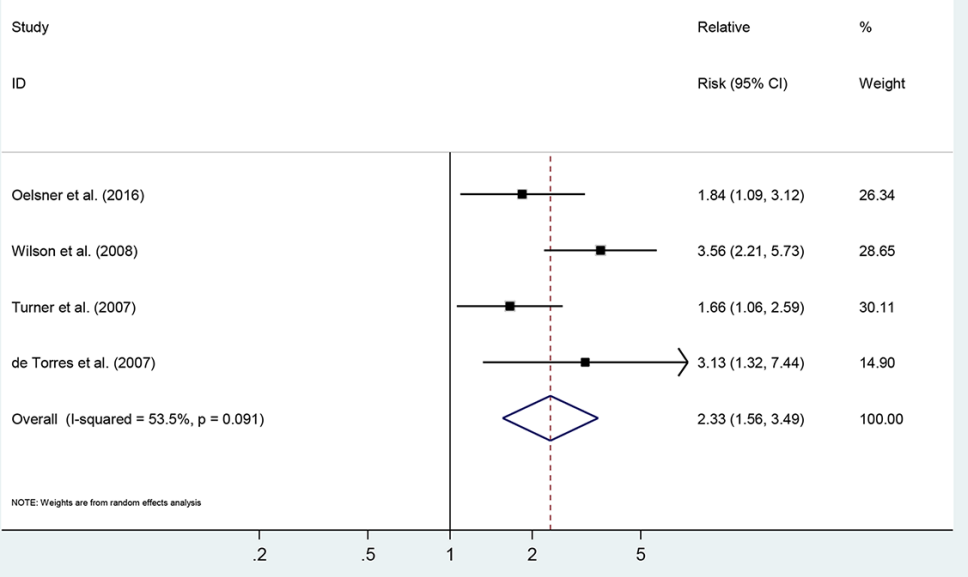

Figure 2: Pooled estimates of the risk associated with a previous diagnosis of chronic obstructive pulmonary disease (COPD), separated by condition. (A) COPD. (B) chronic bronchitis. (C) emphysema. 
Table 2: Subgroup analyses of chronic obstructive pulmonary disease and lung cancer risk

\begin{tabular}{|c|c|c|c|c|c|}
\hline & Studies, n & SRR (95\% CI) & $\mathbf{I}^{2}(\%)$ & $\mathbf{P}_{\text {heterogeneity }}$ & $\mathbf{P}_{\text {difference }}$ \\
\hline All & 14 & $2.06(1.50-2.85)$ & 96.7 & $<0.001$ & \\
\hline Sex & & & & & 0.399 \\
\hline Male & 6 & $2.04(1.11-3.74$ & 98.3 & $<0.001$ & \\
\hline Female & 3 & $2.67(1.27-5.59)$ & 93.3 & $<0.001$ & \\
\hline Locations & & & & & 0.029 \\
\hline Europe & 4 & $2.40(1.81-3.18)$ & 49.3 & 0.116 & \\
\hline USA & 8 & $1.65(1.32-2.05)$ & 84.0 & $<0.001$ & \\
\hline Asia & 2 & $2.99(1.18-7.60)$ & 98.7 & $<0.001$ & \\
\hline Smoking status & & & & & 0.289 \\
\hline Never & 3 & $2.32(1.42-3.77)$ & 0 & 0.833 & \\
\hline Ever & 3 & $1.60(1.28-2.01)$ & 76.0 & $<0.001$ & \\
\hline $\begin{array}{l}\text { Diagnosis of } \\
\text { COPD }\end{array}$ & & & & & 0.201 \\
\hline $\begin{array}{l}\text { Physiological } \\
\text { diagnosis }\end{array}$ & 6 & $2.02(1.69-2.41)$ & 0 & 0.931 & \\
\hline Disease registry & 3 & $2.75(0.87-8.73)$ & 99.4 & $<0.001$ & \\
\hline Self-report & 5 & $1.75(1.40-2.19)$ & 80.2 & $<0.001$ & \\
\hline COPD severity & & & & & 0.016 \\
\hline Mild & 4 & $1.46(1.20-1.76)$ & 0 & 0.876 & \\
\hline Moderate & 3 & $2.05(1.67-2.52)$ & 8.1 & 0.337 & \\
\hline Severe & 3 & $2.44(1.73-3.45)$ & 0 & 0.438 & \\
\hline Follow-up, years & & & & & 0.453 \\
\hline$\leq 5$ & 7 & $1.87(1.36-2.59)$ & 89.3 & $<0.001$ & \\
\hline$>5$ & 7 & $2.23(1.41-3.53)$ & 96.3 & $<0.001$ & \\
\hline Type of outcome & & & & & 0.948 \\
\hline Incidence & 10 & $2.06(1.34-3.16)$ & 97.6 & $<0.001$ & \\
\hline Mortality & 4 & $1.95(1.71-2.23)$ & 0 & 0.775 & \\
\hline
\end{tabular}

plot, and the summary risk estimates were still statistically significant, albeit weaker (SRR $=1.37$; 95\% CI, 1.01-1.92; Figure 3). We did not evaluate the publication bias for the association of emphysema and chronic bronchitis due to the small number of studies included.

\section{DISCUSSION}

Based on eighteen prospective cohort studies, our meta-analysis provides the most comprehensive evidence that a significantly increased risk of lung cancer was observed for a history of COPD, emphysema, but not for chronic bronchitis. In addition, increased risk of lung cancer for COPD was seen for both men and women and among all the location subgroups. Importantly, the increased risk was significantly higher for squamous cell cancer than those for adenocarcinoma and for small cell cancer, and was COPD severity dependent.

Several mechanisms have been suggested to explain the predisposition of patients with COPD to develop lung cancer. First, mucociliary dysfunction caused by COPD may allow carcinogens from the smoke or other environmental substances in the mucous blanket to have longer exposure time at these sites, leading to development of lung cancer [48]. Secondly, airway obstruction in COPD may lead to chronic inflammation, which can result in increase the likelihood of the conversion of endogenous DNA damage into mutations. Thirdly, an imbalance between oxidants and antioxidants can lead to free radical damage of DNA [49]. Fourthly, there may be some genetic 
predisposition to both diseases as the familial clustering of pulmonary dysfunction in relatives of patients with lung cancer and in patients with COPD [50].

Both chronic bronchitis and emphysema can lead to chronic airway obstruction and then develop into COPD. Our finding showed that emphysema, but not chronic bronchitis, was a risk factor for the development of lung cancer. Results from a prospective cohort [12] of a lung cancer screening study showed that emphysema, but not airflow obstruction, is an independent risk factor for lung cancer. Wilson et al. [14] reported that although emphysema on CT scan and airflow obstruction on spirometry are related to lung cancer in a high-risk population, the former had a higher risk for lung cancer compared to the latter. By contrast, other studies $[51,52]$ found that emphysema was not a significant risk for lung cancer. Given the observational evidence and the low numbers of lung cancer events, these results may be prone to type II error.

In the current report, we found that the pooled risk association between COPD and lung cancer risk was severity dependent. That is, lung cancer incidence increased in a stepwise manner from the severity of COPD. A study from Calabro et al. [53] provided accurate quantification that lung function impairment was associated with a significantly increased risk of lung cancer: a reduction of as little as $10 \%$ of $\mathrm{FEV}_{1} \%$ pred is associated with an almost three-fold greater lung cancer risk. A recent meta-analysis [54] revealed that reduced FEV1 is strongly associated with risk of lung cancer, especially among women. Importantly, authors found that the risk relationship is dose- dependant. However, a study by de Torres et al [18] reported that incidence density of lung cancer is higher in COPD patients with milder airflow obstruction (19.9 per 1,000 person-yrs) than that with severe airflow obstruction (9.2 per 1,000 person-yrs). Authors speculated that patients with severe COPD have an active, non-tolerant, immune system, which would act as a barrier for the development and progression of lung cancer.

Analyses stratified by lung cancer histology can offer insight into the relationship between COPD and lung cancer. In the current meta-analysis, although not statistically significant, COPD cases had an increased risk of squamous cell carcinoma, small cell cancer and adenocarcinoma of the lung (SRR, 1.85 vs. 1.39 vs. 1.25). In contrast to the well established finding that smoking is a stronger risk factor for squamous cell carcinoma and small cell carcinoma than for adenocarcinoma of the lung [55], our findings for COPD showed a different pattern. Papi et al. [56] have reported that COPD might increase the risk of the squamous cell cancer by more than four

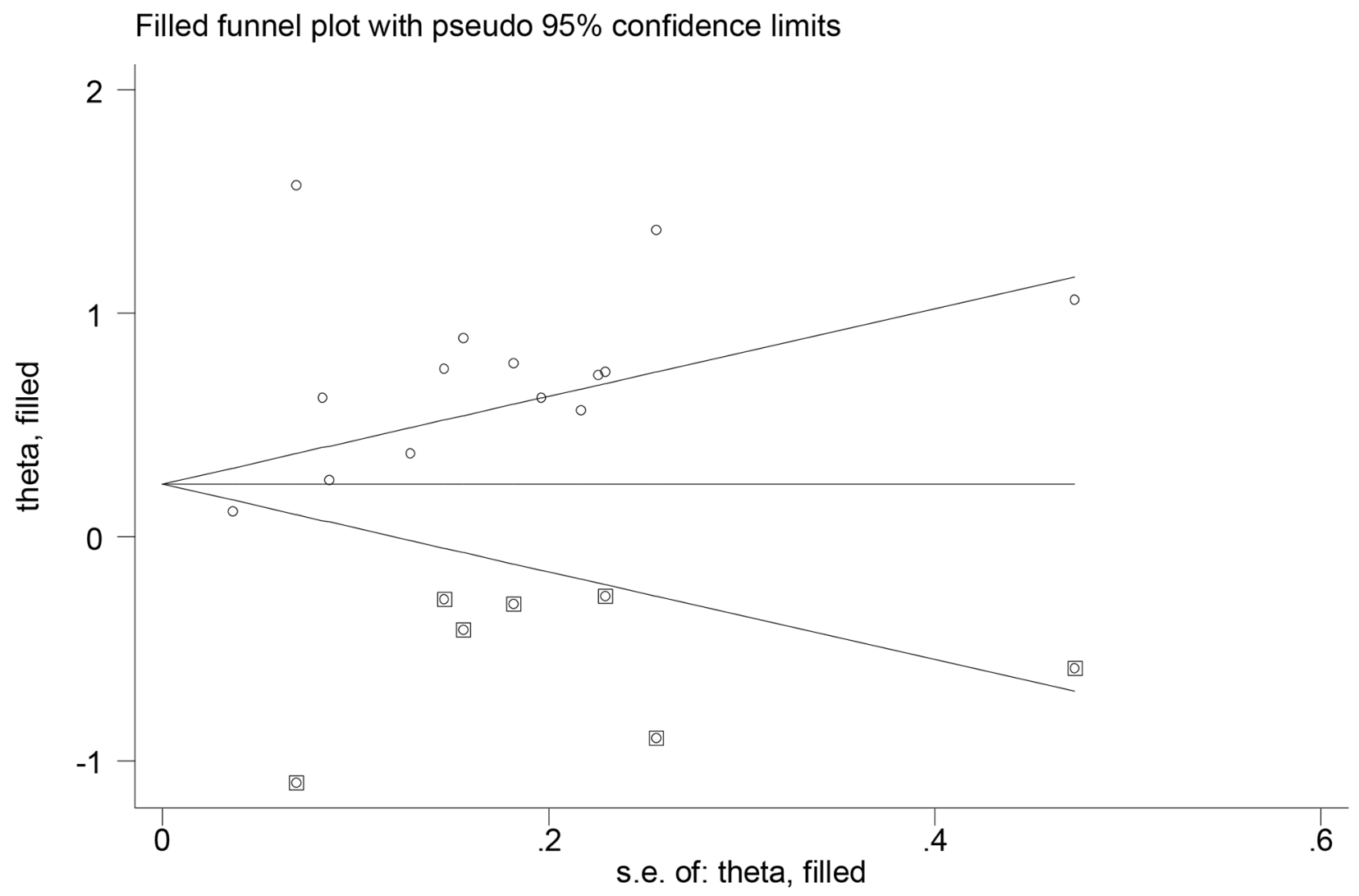

Figure 3: Filled funnel plot of log relative risk vs. standard error of log relative risks in studies that evaluated the effect of chronic obstructive pulmonary disease on the risk of lung cancer. 
times (OR=4.05, 95\%CI, 1.93 to 10.57). These differences by histology support the notion that tobacco smoke may exert effects on the association between COPD and lung cancer. However, these results should be interpreted with caution because the current sub-analysis was based on only two studies. Further studies are warrant to clarify the association between COPD and lung cancer histology.

Our study has several strengths as follows: (1) we were able to update a number of recently published studies on the COPD-lung cancer association; (2) we could derive risk estimates with high levels of precision and the less possibility of recall or selection bias, because our analysis was according to eighteen prospective cohort studies, involving more than 10,000 lung cancer cases and 9 million participants; (3) We performed several sensitivity analysis based on sex, geographic locations, smoking status, exposure assessment, COPD severity, duration of follow-up, lung cancer histology in the COPD-lung cancer association.

There are several design and methodological limitations of this study that must be considered in the interpretation of the results. First, this meta-analysis detected great heterogeneity across studies. We performed meta-regression analyses showed that study locations have modified effects on this association, which might partially $(36.3 \%)$ account for the high heterogeneity among studies.

Second, misclassification bias may exist. A history of COPD was ascertained by self-report in four studies, which lead to the attenuation of risk estimates and the true COPD-lung cancer association may be stronger than we observed. Although the precise definitions and diagnoses of COPD vary, some studies [57, 58] have attempted to verify self-reported history of COPD by the presence of airflow limitation due to chronic bronchitis and emphysema, with a sensitivity of $12.5 \%[58]$ to $78 \%$ [57]. Indeed, a sensitivity analysis by stratifying the total studies based on the methods of COPD diagnosis did not find a significant difference in the SRRs among methods of COPD assessment.

Third, because of the observational nature of our analysis, unmeasured and residual confounding is likely to be present. It has been debated that the COPD-lung cancer relationship may be a product of residual confounding by tobacco smoking, the shared risk factor for both COPD and lung cancer [44]. In our meta-analysis, we included only studies that controlled for the effects of smoking (status, intensity and duration). We further performed analyses according to smoking status, and found that the increased COPD-lung cancer association was independent of smoking status and the magnitude of the association was similar between never and ever smoking. Additionally, some confounding factors were not considered, such as biofuel smoke and second hand smoke (SHS), which is a shared risk factor for lung cancer [59] and COPD [60].

Forth, the effect of medications for COPD on this association should also be taken into account. To date, results from observational studies have suggested the potential that inhaled corticosteroids (ICS), which are commonly prescribed to COPD patients, may exert a protective role against the development and progression of lung cancer, particularly at high doses [61]. However, no studies involved in this meta-analysis considered the effects of ICS on the association between COPD and the risk of lung cancer.

Finally, the possibility of publication bias is of a concern, because small studies with null results tend not to be published. Although Begg's and Egger's tests did not reveal evidence of publication bias, visual inspection of the funnel plots did reveal significant asymmetry. The trim-and-fill method suggested 7 additional risk estimates were needed to balance the funnel plot, and the summary risk estimates were still statistically significant, albeit weaker $(\mathrm{SRR}=1.37)$.

In conclusion, the present study suggests a significantly increased risk of lung cancer associated with history of COPD. However, the possibility that the association may be due to bias or confounding cannot be completely excluded.

\section{MATERIALS AND METHODS}

\section{Data sources and study identification}

Two investigators ( $\mathrm{ZXY}$ and $\mathrm{JN}$ ) independently screened the original articles published in English language in MEDLINE and EMBASE databases from inception to December 31, 2016. We used the list of keywords in the form of following MeSH terms and Text Words: 1). COPD OR chronic obstructive pulmonary disease OR emphysema OR chronic bronchitis; 2) lung cancer OR lung neoplasm; 3) risk OR incidence OR prevalence OR mortality. References of selected retrieved articles were also manually searched. We did not consider abstracts or unpublished reports.

\section{Study selection}

COPD is a term generally used to describe two end phenotypes: emphysema (the enlargement and destruction of the alveoli) and chronic bronchitis (chronic inflammation and scarring of bronchi), and the majority of patients with COPD are found somewhere in the middle. The most common definitions of COPD involve either airflow limitation (American Thoracic Society) or reduced maximum expiratory flow (European Respiratory Society). The present meta-analysis was based on estimates reported for these three conditions combined as well as reported separately (i.e., COPD, emphysema, chronic bronchitis).

Two authors (ZXY and JN) independently reviewed all the retrieved studies to determine if they meet the inclusion criteria and disagreements were settled through consensus with a third investigator (WLJ). The inclusion criteria were as follows: 
(1) published as original prospective cohort studies reporting incidence or mortality of lung cancer after the diagnosis of COPD (including emphysema and/or chronic bronchitis);

(2) reported findings in terms of relative risk (RR), hazard ratio(HR), with corresponding $95 \%$ CIs or that reporting sufficient data to calculate them;

(3) adjusted or matched the risk estimations with age and smoking at least.

Non peer-reviewed articles, animal and mechanistic studies, ecologic assessments and correlation studies were not included for analysis. In case of several publications describing the same study, only the most recent or informative publication was included.

\section{Data extraction}

The following information was extracted from each study by two researchers (ZXY and JN) independently: last name of the first author, study design, publication year, geographic locations, study size, study population, methods of COPD and lung cancer ascertainment, followup duration, the RR estimates with their 95\% CI and adjustment variables. From each study, the risk estimates were extracted that have been adjusted for the greatest number of potential confounders. To ensure the accuracy of data extraction, this process was independently performed by three authors (JN, ZXY and WLJ). Any data discrepancy was also resolved by consensus.

\section{Statistical methods}

Data analysis was performed using STATA, version 11.0 (STATA, College Station, TX, USA) statistical software. A two-tailed $\mathrm{P}$ value of $<0.05$ represents significance. In light of the high likelihood of between study variance, we used a random-effect model rather than a fixed-effect model. This method of a random-effects model was developed by DerSimonian and Laird [62]. Because mortality among lung cancer patients is quite high (5-year survival $\sim 10-15 \%$ among western populations), we used mortality as a proxy measure for incidence. We used a fixed effects model to obtain overall combined estimates for lung cancer risk for studies that reported results separately for diabetes and non-diabetes [21], COPD severity [13, 45]. For studies reporting risk estimations for chronic bronchitis, emphysema and/or COPD [12, 14, 47], we used them in the specific meta-analysis.

Heterogeneity was assessed by Cochran $Q$ and $I^{2}$ statistics. $\mathrm{P}$ value of $<0.10$ represents statistically significant heterogeneity. $I^{2}$ values quantify the proportion of total variation across studies that is due to heterogeneity rather than chance, with the low, moderate, and high of $25 \%, 50 \%$, and $75 \%$ respectively. Where the $I^{2}$ value was $25 \%$ or lower, indicating no evidence of heterogeneity [63]. Sources of heterogeneity were explored using subgroup analyses and meta-regression analysis. We also investigated the influence of a single study on the overall risk estimate by sequentially removing study to test the robustness of the main results. Where possible, potential publication bias was assessed by visual inspection of the funnel plots and the further Begg's adjusted rank correlation and Egger's regression asymmetry test [64, 65]. The $P$ values of $<0.10$ indicates potential publication bias. In addition, we evaluated the number of unpublished studies that would have to exist to negate the results and the pooled RR adjusted for publication bias using the trim and fill method [66].

\section{Abbreviations}

COPD, chronic obstructive pulmonary disease; GBD, Global Burden of Disease; FEV, forced expiratory volume; $\mathrm{CB}$, chronic bronchitis; RR, relative risks; $\mathrm{CI}$, confidence interval; HR, hazard ratio.

\section{Author contributions}

Xinyue Zhang and Ning Jiang participated in the design of this manuscript. Xinyue Zhang, Ning Jiang and Lijuan Wang participated in abstracting the data, Ning Jiang, Huaman Liu and Rong He participated in performing statistical analysis. All authors read and approved the final manuscript.

\section{CONFLICTS OF INTEREST}

None.

\section{FINANCIAL SUPPORT}

No funding.

\section{REFERENCES}

1. GBD 2013 Mortality and Causes of Death Collaborators. Global, regional, and national age-sex specific all-cause and cause-specific mortality for 240 causes of death, 1990-2013: a systematic analysis for the Global Burden of Disease Study 2013. Lancet. 2016; 385: 117-71.

2. Guo Y, Zhang T, Wang Z, Yu F, Xu Q, Guo W, Wu C, He $\mathrm{J}$. Body mass index and mortality in chronic obstructive pulmonary disease: A dose-response meta-analysis. Medicine (Baltimore). 2016; 95: e4225.

3. Shlomi D, Ben-Avi R, Balmor GR, Onn A, Peled N. Screening for lung cancer: time for large-scale screening by chest computed tomography. Eur Respir J. 2014; 44: 217-38 
4. Mathers CD, Loncar D. Projections of global mortality and burden of disease from 2002 to 2030. PLoS Med. 2006; 3: e442.

5. Sekine Y, Katsura H, Koh E, Hiroshima K, Fujisawa T. Early detection of COPD is important for lung cancer surveillance. Eur Respir J. 2012; 39: 1230-40.

6. Brenner DR, McLaughlin JR, Hung RJ. Previous lung diseases and lung cancer risk: a systematic review and meta-analysis. PLoS One. 2011; 6: e17479.

7. Wang H, Yang L, Zou L, Huang D, Guo Y, Pan M, Tan Y, Zhong H, Ji W, Ran P, Zhong N, Lu J. Association between chronic obstructive pulmonary disease and lung cancer: a case-control study in Southern Chinese and a meta-analysis. PLoS One. 2012; 7: e46144.

8. Nomura A, Stemmermann GN, Chyou PH, Marcus EB, Buist AS. Prospective study of pulmonary function and lung cancer. Am Rev Respir Dis. 1991; 144: 307-11.

9. Vestbo J, Knudsen KM, Rasmussen FV. Are respiratory symptoms and chronic airflow limitation really associated with an increased risk of respiratory cancer? Int J Epidemiol. 1991; 20: 375-8.

10. Mannino DM, Buist AS, Petty TL, Enright PL, Redd SC. Lung function and mortality in the United States: data from the First National Health and Nutrition Examination Survey follow up study. Thorax. 2003; 58: 388-93.

11. Littman AJ, Thornquist MD, White E, Jackson LA, Goodman GE, Vaughan TL. Prior lung disease and risk of lung cancer in a large prospective study. Cancer Causes Control. 2004; 15: 819-27.

12. de Torres JP, Bastarrika G, Wisnivesky JP, Alcaide AB, Campo A, Seijo LM, Pueyo JC, Villanueva A, Lozano MD, Montes U, Montuenga L, Zulueta JJ. Assessing the relationship between lung cancer risk and emphysema detected on low-dose CT of the chest. Chest. 2007; 132: 1932-8.

13. Purdue MP, Gold L, Jarvholm B, Alavanja MC, Ward MH, Vermeulen R. Impaired lung function and lung cancer incidence in a cohort of Swedish construction workers. Thorax. 2007; 62: 51-6.

14. Wilson DO, Weissfeld JL, Balkan A, Schragin JG, Fuhrman CR, Fisher SN, Wilson J, Leader JK, Siegfried JM, Shapiro $\mathrm{SD}$, Sciurba FC. Association of radiographic emphysema and airflow obstruction with lung cancer. Am J Respir Crit Care Med. 2008; 178: 738-44.

15. Mortensen EM, Copeland LA, Pugh MJ, Fine MJ, Nakashima B, Restrepo MI, de Molina RM, Anzueto A. Diagnosis of pulmonary malignancy after hospitalization for pneumonia. Am J Med. 2010; 123: 66-71.

16. van Gestel YR, Hoeks SE, Sin DD, Huzeir V, Stam H, Mertens FW, van Domburg RT, Bax JJ, Poldermans D. COPD and cancer mortality: the influence of statins. Thorax. 2009; 64: 963-7.

17. Rodriguez LA, Wallander MA, Martin-Merino E, Johansson S. Heart failure, myocardial infarction, lung cancer and death in COPD patients: a UK primary care study. Respir Med. 2010; 104: 1691-9.

18. de Torres JP, Marin JM, Casanova C, Cote C, Carrizo S, Cordoba-Lanus E, Baz-Davila R, Zulueta JJ, Aguirre-Jaime A, Saetta M, Cosio MG, Celli BR. Lung cancer in patients with chronic obstructive pulmonary disease-- incidence and predicting factors. Am J Respir Crit Care Med. 2011; 184: 913-9.

19. Fan YG, Jiang Y, Chang RS, Yao SX, Jin P, Wang W, He J, Zhou QH, Prorok P, Qiao YL, Hu P. Prior lung disease and lung cancer risk in an occupational-based cohort in Yunnan, China. Lung Cancer. 2011; 72: 258-63.

20. Leung CC, Lam TH, Yew WW, Law WS, Tam CM, Chang $\mathrm{KC}$, McGhee S, Tam SY, Chan KF. Obstructive lung disease does not increase lung cancer mortality among female never-smokers in Hong Kong. Int J Tuberc Lung Dis. 2012; 16: 546-52.

21. Shen TC, Chung WS, Lin CL, Wei CC, Chen $\mathrm{CH}$, Chen HJ, Tu CY, Hsia TC, Shih CM, Hsu WH, Chung CJ. Does chronic obstructive pulmonary disease with or without type 2 diabetes mellitus influence the risk of lung cancer? Result from a population-based cohort study. PLoS One. 2014; 9: e98290.

22. Aldrich MC, Munro HM, Mumma M, Grogan EL, Massion PP, Blackwell TS, Blot WJ. Chronic obstructive pulmonary disease and subsequent overall and lung cancer mortality in low-income adults. PLoS One. 2015; 10: e0121805.

23. Marcus MW, Chen Y, Raji OY, Duffy SW, Field JK. LLPi: Liverpool Lung Project Risk Prediction Model for Lung Cancer Incidence. Cancer Prev Res (Phila). 2015; 8: 570-5.

24. Oelsner EC, Carr JJ, Enright PL, Hoffman EA, Folsom AR, Kawut SM, Kronmal RA, Lederer DJ, Lima JA, Lovasi GS, Smith BM, Shea SJ, Barr RG. Per cent emphysema is associated with respiratory and lung cancer mortality in the general population: a cohort study. Thorax. 2016; 71: 624-32.

25. Little J, Logan RF, Hawtin PG, Hardcastle JD, Turner ID. Colorectal adenomas and diet: a case-control study of subjects participating in the Nottingham faecal occult blood screening programme. Br J Cancer. 1993; 67: 177-84.

26. Neugut AI, Garbowski GC, Lee WC, Murray T, Nieves JW, Forde KA, Treat MR, Waye JD, Fenoglio-Preiser C. Dietary risk factors for the incidence and recurrence of colorectal adenomatous polyps. A case-control study. Ann Intern Med. 1993; 118: 91-5.

27. Martinez ME, McPherson RS, Annegers JF, Levin B. Association of diet and colorectal adenomatous polyps: dietary fiber, calcium, and total fat. Epidemiology. 1996; 7: 264-8.

28. Terry MB, Neugut AI, Bostick RM, Sandler RS, Haile RW, Jacobson JS, Fenoglio-Preiser CM, Potter JD. Risk factors for advanced colorectal adenomas: a pooled analysis. Cancer Epidemiol Biomarkers Prev. 2002; 11: 622-9. 
29. Terry MB, Neugut AI, Mansukhani M, Waye J, Harpaz N, Hibshoosh H. Tobacco, alcohol, and p53 overexpression in early colorectal neoplasia. BMC Cancer. 2003; 3: 29.

30. Diergaarde B, Tiemersma EW, Braam H, van Muijen GN, Nagengast FM, Kok FJ, Kampman E. Dietary factors and truncating APC mutations in sporadic colorectal adenomas. Int J Cancer. 2005; 113: 126-32.

31. Kandiah M. Nutritional status and the risk for colorectal adenomas: A case-control study in hospital Kuala Lumpur, Malaysia. Pakistan Journal of Nutrition. 2010; 9: 269-78.

32. Northwood EL, Elliott F, Forman D, Barrett JH, Wilkie MJ, Carey FA, Steele RJ, Wolf R, Bishop T, Smith G. Polymorphisms in xenobiotic metabolizing enzymes and diet influence colorectal adenoma risk. Pharmacogenet Genomics. 2010; 20: 315-26.

33. Stroup DF, Berlin JA, Morton SC, Olkin I, Williamson GD, Rennie D, Moher D, Becker BJ, Sipe TA, Thacker SB. Meta-analysis of observational studies in epidemiology: a proposal for reporting. Meta-analysis Of Observational Studies in Epidemiology (MOOSE) group. JAMA. 2000; 283: 2008-12.

34. Qiao YL, Taylor PR, Yao SX, Erozan YS, Luo XC, Barrett MJ, Yan QY, Giffen CA, Huang SQ, Maher MM, Forman MR, Tockman MS. Risk factors and early detection of lung cancer in a cohort of Chinese tin miners. Ann Epidemiol. 1997; 7: 533-41.

35. Wu CY, Hu HY, Pu CY, Huang N, Shen HC, Li CP, Chou YJ. Pulmonary tuberculosis increases the risk of lung cancer: a population-based cohort study. Cancer. 2011; 117: 618-24.

36. Yu YH, Liao CC, Hsu WH, Chen HJ, Liao WC, Muo CH, Sung FC, Chen CY. Increased lung cancer risk among patients with pulmonary tuberculosis: a population cohort study. J Thorac Oncol. 2011; 6: 32-7.

37. Kornum JB, Svaerke C, Thomsen RW, Lange P, Sorensen HT. Chronic obstructive pulmonary disease and cancer risk: a Danish nationwide cohort study. Respir Med. 2012; 106: 845-52.

38. Young RP, Duan F, Chiles C, Hopkins RJ, Gamble GD, Greco EM, Gatsonis C, Aberle D. Airflow Limitation and Histology Shift in the National Lung Screening Trial. The NLST-ACRIN Cohort Substudy. Am J Respir Crit Care Med. 2015; 192: 1060-7.

39. Kiri VA, Soriano J, Visick G, Fabbri L. Recent trends in lung cancer and its association with COPD: an analysis using the UK GP Research Database. Prim Care Respir J. 2010; 19: 57-61.

40. Jian ZH, Lung CC, Huang JY, Ko PC, Jan SR, Ndi Nfor $\mathrm{O}, \mathrm{Ku}$ WY, Ho CC, Pan HH, Liaw YP. The coexistence of common pulmonary diseases on the histologic type of lung cancer in both genders in Taiwan: a STROBE-compliant article. Medicine (Baltimore). 2014; 93: e127.

41. Gershon A, Hwee J, Victor JC, Wilton A, Wu R, Day A, To T. Mortality trends in women and men with COPD in Ontario, Canada, 1996-2012. Thorax. 2015; 70: 121-6.
42. Hsu CK, Lai CC, Wang K, Chen L. Risk of lung cancer in patients with gastro-esophageal reflux disease: a populationbased cohort study. PeerJ. 2016; 4: e2753.

43. Kuller LH, Ockene J, Meilahn E, Svendsen KH. Relation of forced expiratory volume in one second (FEV1) to lung cancer mortality in the Multiple Risk Factor Intervention Trial (MRFIT). Am J Epidemiol. 1990; 132: 265-74.

44. Van den Eeden SK, Friedman GD. Forced expiratory volume (1 second) and lung cancer incidence and mortality. Epidemiology. 1992; 3: 253-7.

45. Mannino DM, Aguayo SM, Petty TL, Redd SC. Low lung function and incident lung cancer in the United States: data From the First National Health and Nutrition Examination Survey follow-up. Arch Intern Med. 2003; 163: 1475-80.

46. Slatore CG, Littman AJ, Au DH, Satia JA, White E. Longterm use of supplemental multivitamins, vitamin C, vitamin $\mathrm{E}$, and folate does not reduce the risk of lung cancer. Am J Respir Crit Care Med. 2008; 177: 524-30.

47. Turner MC, Chen Y, Krewski D, Calle EE, Thun MJ. Chronic obstructive pulmonary disease is associated with lung cancer mortality in a prospective study of never smokers. Am J Respir Crit Care Med. 2007; 176: 285-90.

48. Ghosh A, Boucher RC, Tarran R. Airway hydration and COPD. Cell Mol Life Sci. 2015; 72: 3637-52.

49. Bozinovski S, Vlahos R, Anthony D, McQualter J, Anderson G, Irving L, Steinfort D. COPD and squamous cell lung cancer: aberrant inflammation and immunity is the common link. Br J Pharmacol. 2016; 173: 635-48.

50. Dialyna IA, Miyakis S, Georgatou N, Spandidos DA. Genetic polymorphisms of CYP1A1, GSTM1 and GSTT1 genes and lung cancer risk. Oncol Rep. 2003; 10: 1829-35.

51. Koshiol J, Rotunno M, Consonni D, Pesatori AC, De Matteis S, Goldstein AM, Chaturvedi AK, Wacholder S, Landi MT, Lubin JH, Caporaso NE. Chronic obstructive pulmonary disease and altered risk of lung cancer in a population-based case-control study. PLoS One. 2009; 4: e7380.

52. Brenner DR, Hung RJ, Tsao MS, Shepherd FA, Johnston MR, Narod S, Rubenstein W, McLaughlin JR. Lung cancer risk in never-smokers: a population-based case-control study of epidemiologic risk factors. BMC Cancer. 2010; 10: 285.

53. Calabro E, Randi G, La Vecchia C, Sverzellati N, Marchiano A, Villani M, Zompatori M, Cassandro R, Harari $\mathrm{S}$, Pastorino U. Lung function predicts lung cancer risk in smokers: a tool for targeting screening programmes. Eur Respir J. 2010; 35: 146-51.

54. Wasswa-Kintu S, Gan WQ, Man SF, Pare PD, Sin DD. Relationship between reduced forced expiratory volume in one second and the risk of lung cancer: a systematic review and meta-analysis. Thorax. 2005; 60: 570-5.

55. Seki T, Nishino Y, Tanji F, Maemondo M, Takahashi S, Sato I, Kawai M, Minami Y. Cigarette smoking and lung cancer risk according to histologic type in Japanese men and women. Cancer Sci. 2013; 104: 1515-22. 
56. Papi A, Casoni G, Caramori G, Guzzinati I, Boschetto P, Ravenna F, Calia N, Petruzzelli S, Corbetta L, Cavallesco G, Forini E, Saetta M, Ciaccia A, et al. COPD increases the risk of squamous histological subtype in smokers who develop non-small cell lung carcinoma. Thorax. 2004; 59: 679-81.

57. Barr RG, Herbstman J, Speizer FE, Camargo CA Jr. Validation of self-reported chronic obstructive pulmonary disease in a cohort study of nurses. Am J Epidemiol. 2002; 155: $965-71$.

58. Bobadilla A, Guerra S, Sherrill D, Barbee R. How accurate is the self-reported diagnosis of chronic bronchitis? Chest. 2002; 122: 1234-9.

59. Kim CH, Lee YC, Hung RJ, McNallan SR, Cote ML, Lim WY, Chang SC, Kim JH, Ugolini D, Chen Y, Liloglou T, Andrew AS, Onega T, et al. Exposure to secondhand tobacco smoke and lung cancer by histological type: a pooled analysis of the International Lung Cancer Consortium (ILCCO). Int J Cancer. 2014; 135: 1918-30.

60. Fischer F, Kraemer A. Meta-analysis of the association between second-hand smoke exposure and ischaemic heart diseases, COPD and stroke. BMC Public Health. 2015; 15: 1202.

61. Raymakers AJ, McCormick N, Marra CA, Fitzgerald JM, Sin D, Lynd LD. Do inhaled corticosteroids protect against lung cancer in patients with COPD? A systematic review. Respirology. 2017; 22: 61-70.

62. DerSimonian R, Laird N. Meta-analysis in clinical trials. Control Clin Trials. 1986; 7: 177-88.

63. Higgins JP, Thompson SG, Deeks JJ, Altman DG. Measuring inconsistency in meta-analyses. Bmj. 2003; 327: 557-60.

64. Begg CB, Mazumdar M. Operating characteristics of a rank correlation test for publication bias. Biometrics. 1994; 50: 1088-101.

65. Egger M, Davey Smith G, Schneider M, Minder C. Bias in meta-analysis detected by a simple, graphical test. Bmj. 1997; 315: 629-34.

66. Duval S, Tweedie R. Trim and fill: A simple funnel-plotbased method of testing and adjusting for publication bias in meta-analysis. Biometrics. 2000; 56: 455-63. 